\title{
KOREKSI KEKENDURAN TRAMMEL NET
}

\section{CORRECTION OF TRAMMEL NETSLACKNESS}

\author{
Ratu Sari Mardiah', Gondo Puspito 2 , Mustaruddin ${ }^{2}$ \\ ${ }^{1}$ Program Studi Teknologi Perikanan Laut, Sekolah Pascasarjana \\ Universitas Sultan Ageng Tirtayasa \\ ${ }^{2}$ Departemen Pemanfaatan Sumberdaya Perikanan, \\ Fakultas Perikanan dan Ilmu Kelautan, Institut Pertanian Bogor \\ Korespondensi: ratu_sari28@yahoo.com, gondopuspito@gmail.com,mus_m03@yahoo.com
}

\begin{abstract}
Trammel net has ability to catch demersal organisms which is dominated at the bottom of its net body. It is caused the slackness of trammel net is only found at that section. This study tried to increase the slackness of the nets at the different positions. The aims are to determine the catchs composition and to prove whether the increasing of the slackness will affect the number of catchs. This research was conducted by using 3 trammel nets as control (TK) with one slackness and 3 treated trammel nets (TP) with 3 slackness. The whole trammel net were operated with total of 35 settings at Lontar waters. The results showed that the increasing of slackness did not affect the catchs composition. Each trammel net resulted the same composition of catchs, namely four species of shrimps, ten species of demersal fishes, two species of crabs and one species of non demersal fishes. Trammel net TP resulted 581 individuals $(20,10$ $\mathrm{kg}$ ) which is higher than trammel net TK with 277 individuals $(7,38 \mathrm{~kg})$.
\end{abstract}

Keyword: demersal organism, non demersal organism, slackness, trammel net

\begin{abstract}
ABSTRAK
Kemampuan trammel net menangkap organisme demersal terpusat pada bagian bawahnya. Ini disebabkan oleh kekenduran jaring hanya terdapat pada bagian tersebut. Desain trammel net dalam penelitian ini memiliki 3 kekenduran pada posisi ketinggian yang berbeda. Tujuannya adalah untuk menentukan apakah penambahan kekenduran akan merubah komposisi jenis hasil tangkapan dan membuktikan bahwa penambahan kekenduran dapat meningkatkan jumlah hasil tangkapan. Penelitian menggunakan 3 trammel net kontrol (TK) yang memiliki 1 kekenduran dan 3 trammel net perlakuan (TP) dengan 3 kekenduran. Kedua konstruksi trammel net disusun berselang-seling dan dioperasikan secara bersamaan sebanyak 35 setting. Hasilnya menunjukkan bahwa penambahan kekenduran tidak mempengaruhi komposisi jenis hasil tangkapan. Masing-masing trammel net menghasilkan jenis tangkapan yang sama, yaitu 4 jenis udang, 10 jenis ikan demersal, 2 jenis kepiting dan 1 jenis ikan non demersal. Trammel net TP menangkap 581 individu $(20,10 \mathrm{~kg})$, atau lebih tinggi dibandingkan dengan trammel net TK 277 individu $(7.38 \mathrm{~kg})$.
\end{abstract}

Kata kunci: kekenduran, organisme demersal, organisme non demersal, trammel net 


\section{PENDAHULUAN}

\section{Latar belakang}

Trammel net dikelompokkan sebagai bottom gillnet yang dianggap sangat efektif untuk menangkap jenis-jenis organisme demersal. Pengoperasiannya dilakukan dengan 2 cara, yaitu trammel net dihanyutkan mengikuti arus atau salah satu ujung tali ris atasnya ditarik membentuk $1 / 2$ lingkaran. Sapuan trammel net akan menangkap beragam organisme demersal yang hidup di dasar perairan.

Kemampuan trammel net menangkap organisme demersal sebenarnya masih belum maksimal. Hampir seluruh organisme hanya tertangkap pada bagian bawahnya. Adapun bagian atasnya relatif bersih dari hasil tangkapan. Penyebab utamanya terdapat pada konstruksi dan material pembentuk jaringnya.

Konstruksi utama trammel net tersusun atas 2 jaring lapisan luar (outer net) dan 1 jaring lapisan dalam (inner net). Tinggi jaring outer net lebih rendah dibandingkan dengan inner net. Kedua jaring outer net dibentuk menjadi bidang trapesium. Caranya adalah kedua jaring disusun menggunakan rasio penggantungan primer yang berbeda, yaitu rasio penggantungan jaring bagian atas lebih rendah dibandingkan dengan bagian bawah. Sementara jaring inner net diposisikan di antara kedua jaring outer net. Kontruksi demikian menjadikan jaring outer net akan menegang, sedangkan jaring inner net akan mengendur. Selanjutnya, jaring bagian dalam akan bertumpuk di bagian bawah ketika trammel net ditenggelamkan ke dalam laut. Ini dikarenakan material pembentuk jaring berupa polyamide (PA) yang memiliki berat jenis $1.140 \mathrm{kgf} / \mathrm{m} 3$, atau lebih tinggi dari air laut $1.025 \mathrm{kgf} / \mathrm{m} 3$ (Puspito 2009a).

Ketegangan jaring inner netyang tinggi pada bagian atas trammel net memperkecil peluang organisme demersal tertangkap. Upaya yang dapat dilakukan untuk mengantisipasinya adalah menambahkan kekenduran jaring inner net pada beberapa ketinggian. Cara ini diharapkan dapat meningkatkan hasil tangkapan trammel net, karena organisme demersal dan non demersal dapat tertangkap pada semua bagian jaring. Posisi kekenduran jaring inner net pada tiga tempat, yaitu bagian bawah, tengah dan atas. Jaring inner net pada bagian bawah dan tengah trammel net difokuskan untuk menangkap organisme demersal, sedangkan organisme non demersal diharapkan tertangkap pada jaring inner net bagian tengah dan atas. Tujuannya adalah untuk menentukan apakah penambahan kekenduran akan merubah komposisi jenis hasil tangkapan dan membuktikan bahwa penambahan kekenduran dapat meningkatkan jumlah hasil tangkapan. Hipotesis dalam penelitian ini adalah penambahan kekenduran pada beberapa posisi jaring akan meningkatkan hasil tangkapan nelayan.

Penelitian yang membahas perbaikan atau penambahan kekenduran pada beberapa bagian trammel net untuk meningkatkan jumlah hasil tangkapan belum pernah dilakukan sebelumnya. Tiga hasil penelitian yang didapat membahas materi yang berbeda. Irhamsyah (2002) mengkaji pembentukan kantong pada trammel net tanpa memperhitungkan faktorfaktor eksternal yang mempengaruhinya. Puspito (2009b) mempelajari pengaruh arus terhadap tegangan dan bentuk kelengkungan model trammel net untuk memperkirakan luas wilayah sapuan jaring selama operasi penangkapan. Stergiou et al. (2006) menganalisis komposisi spesies hasil tangkapan dan operasi penangkapan dengan trammel net di perairan Eropa selatan. Ketiga pustaka tersebut dijadikan sebagai bahan masukan dalam membahas hasil penelitian ini.

\section{METODE PENELITIAN}

Penelitian dirancang menggunakan metode percobaan. Caranya dengan menguji coba trammel net, baik dengan perlakuan dan tanpa perlakuan, secara langsung di perairan Lontar, Kabupaten Serang, Banten. Gambar 1 menunjukkan lokasi penelitian. Penelitian berlangsung selama 7 hari pada bulan Januari 2016. Sebanyak 5 operasi penangkapan dilakukan dalam 1 hari pada selang waktu antara jam 04.00-14.00 WIB.

Trammel net yang dioperasikan terdiri atas 2 konstruksi, yaitu trammel net kontrol (TK) yang memiliki 1 kekenduran dan trammel net perlakuan (TP) dengan 3 kekenduran. Setiap konstruksi trammel net berjumlah 3 lembar. Gambar 2 mengilustrasikan tampilan sisi trammel net berdasarkan posisi kekenduran. Spesifikasi 1 lembar trammel net dituliskan pada Tabel 1 . 


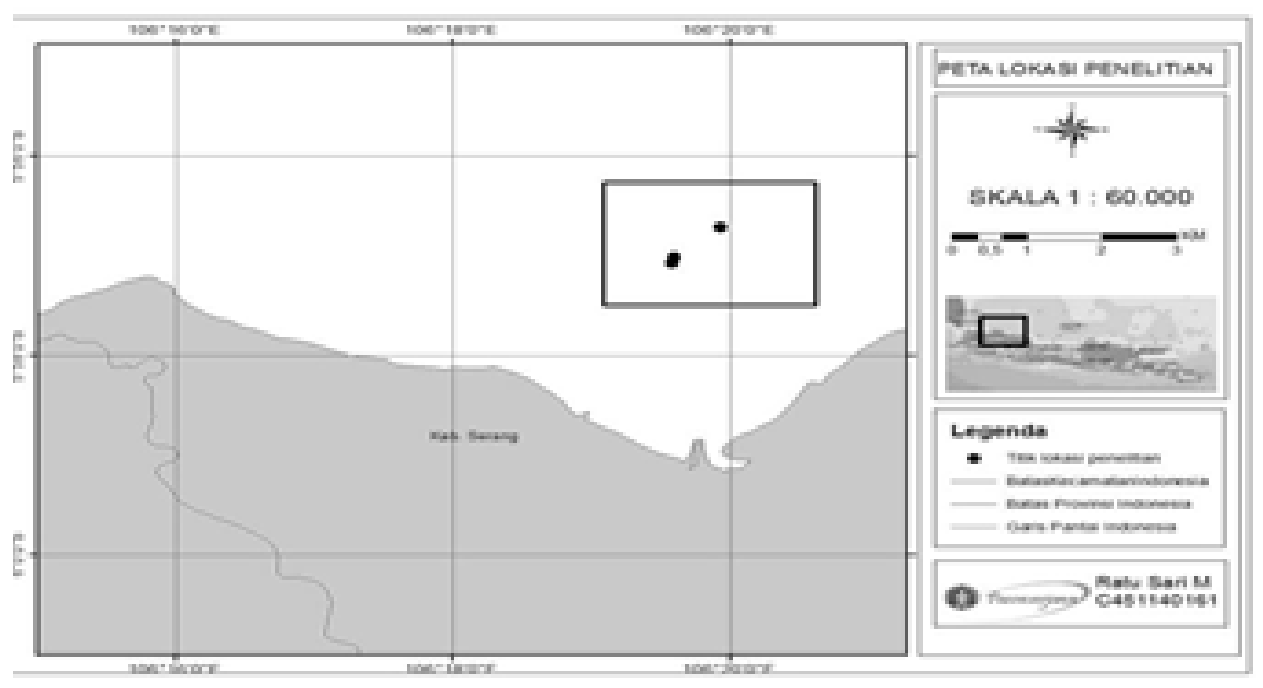

Gambar 1. Lokasi penelitian
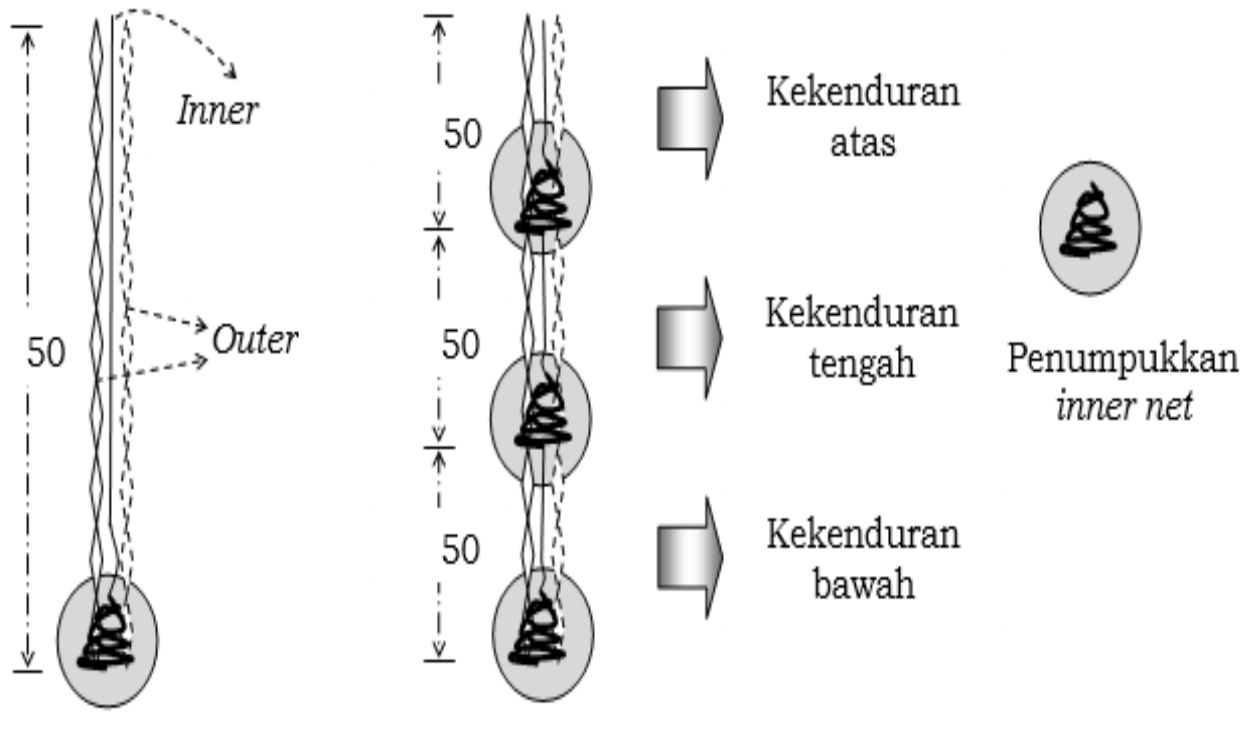

Kekenduran

bawah

Gambar 2. Ilustrasi tampilan sisi trammel net berdasarkan posisi kekenduran

Tabel 1. Spesifikasi 1 lembar trammel net

\begin{tabular}{|c|c|c|}
\hline No. & Nama bagian & Keterangan \\
\hline 1. & $\begin{array}{l}\text { Badan jaring } \\
\text { a. Inner net } \\
\text { b. Outer net }\end{array}$ & $\begin{array}{l}\text { Polyamide (PA), ukuran mata } 1,75 \text { ", ukuran jaring } 1.242 \times 45 \text { (mata) } \\
\text { Polyamide (PA), ukuran mata } 7 \text { ", ukuran jaring } 240 \times 9 \text { (mata). }\end{array}$ \\
\hline 2. & Selvedge & Polyethilene $(\mathrm{PE})$, ukuran mata $1,75^{\prime}$ \\
\hline 3. & Tali Ris & Polyethilene (PE), ø $4 \mathrm{~mm}$, panjang atas 25 dan bawah $33 \mathrm{~m}$ \\
\hline 4. & Tali pelampung & Polyethilene (PE), ø $4 \mathrm{~mm}$, panjang $25 \mathrm{~m}$ \\
\hline 5. & Tali Pemberat & Polyethilene (PE); ø 2,5 mm ; Panjang $33 \mathrm{~m}$ \\
\hline 6. & Pelampung & Sterofoam, 80 buah \\
\hline 7. & Pemberat & Timah, 100 keping \\
\hline
\end{tabular}


Setiap operasi penangkapan menggunakan 3 lembar trammel net TK dan 3 lembar trammel net TP yang disusun berselang-seling (Gambar 3a). Tujuh lembar trammel net milik nelayan (TN) ditempatkan di awal dan akhir rangkaian. Prosedur pengoperasiannya mengikuti urutan berikut:

1. Persiapan pengoperasian trammel net yang meliputi pengecekkan kondisi perahu, mesin penggerak, alat tangkap, bahan bakar dan perbekalan ABK;

2. Perjalanan menuju lokasi penangkapan dan penentuan daerah operasi;

3. Pengoperasian trammel net. Perahu bergerak searah arus sembari melepaskan jangkar, pelampung tanda, jaring dan pemberat tambahan. Ujung tali ris atas jaring terakhir dihubungkan ke perahu menggunakan tali selambar;
4. Perahu menarik jaring selama 45 menit membentuk $1 / 2$ lingkaran (Gambar 3b);

5. Proses pengangkatan trammel net diawali dengan pengangkatan pemberat tambahan, jaring, jangkar dan terakhir pelampung tanda. Hasil tangkapan dilepaskan dari jaring selama proses pengangkatan berlangsung. Operasi penangkapan dilanjutkan di lokasi berbeda dengan cara yang sama pada kedalaman antara 4-7 $\mathrm{m}$ dengan tipe dasar perairan berupa lumpur berpasir; dan

6. Hasil tangkapan disortir di atas perahu menjadi 2 kelompok, yaitu hasil tangkapan utama (HTU) dan sampingan (HTS). HTU terdiri atas udang, kepiting dan jenis-jenis ikan demersal, sedangkan HTS berupa ikan non demersal.

a

\begin{tabular}{|l|l|l|l|l|l|l|}
\hline TN & TK & TP & & TK & TP & TN \\
\hline
\end{tabular}

b

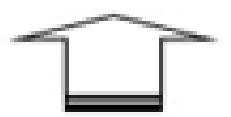

Arus
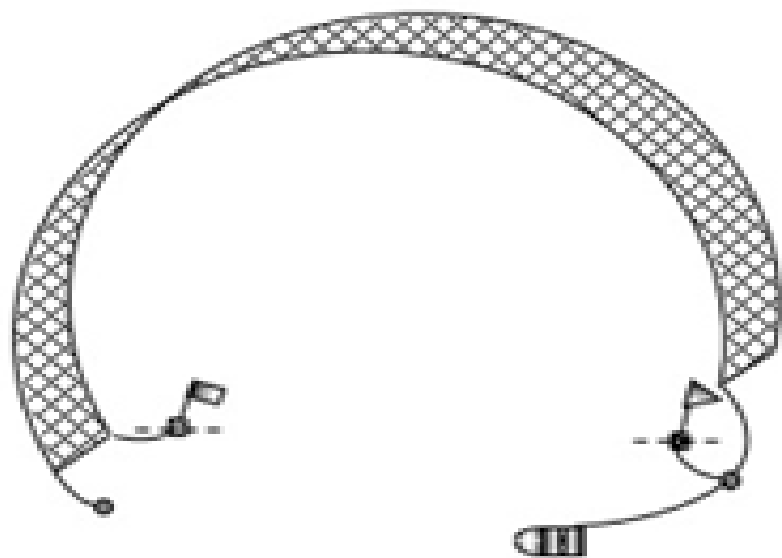

Gambar 3. (a) Susunan trammel net, (b) arah penarikan penarikan trammel net

Data hasil tangkapan berupa berat, jumlah dan jenis organisme tangkapan diplotkan dalam bentuk diagram dan selanjutnya dibandingkan. Jenis uji yang digunakan adalah deskriptif komparatif dan Rancangan Acak Lengkap (RAL) untuk melihat pengaruh perbaikan posisi kekenduran terhadap hasil tangkapan. Analisis RAL dimulai dengan uji kenormalan menggunakan analisis Kolmogorov-Smirnov dan homogenitas. Jika data menyebar normal, maka data dianalisis dengan uji homogenitas dan rancangan acak lengkap (RAL) (Matjik dan Sumertajaya 2000). Hipotesis statistik dalam penelitian ini, HO yaitu perlakuan tidak berpengaruh terhadap hasil tangkapan dan $\mathrm{H} 1$ ada satu perlakuan yang berpengaruh terhadap hasil tangkapan.

\section{HASIL DAN PEMBAHASAN}

\section{Komposisi jenis dan berat hasil tangkapan}

Hasil tangkapan trammel net terdiri atas 17 jenis organisme yang dibagi atas 4 kelompok, yaitu kelompok udang, kepiting, ikan demersal dan ikan non demersal. Hasil tangkapan utamanya adalah organisme demersal yang terdiri atas kelompok udang, kepiting dan ikan demersal. Adapun hasil tangkapan sampingannya berupa organisme non demersal. Jumlah dan berat total hasil tangkapan per konstruksi trammel net dituliskan pada Tabel 2. 
Tabel 2. Jumlah hasil tangkapan trammel net

\begin{tabular}{|c|c|c|c|c|c|c|c|}
\hline \multirow{3}{*}{ No } & \multirow{3}{*}{ Jenis organisme } & \multicolumn{4}{|c|}{ Konstruksi trammel net } & \multirow{2}{*}{\multicolumn{2}{|c|}{ Total }} \\
\hline & & \multicolumn{2}{|c|}{ Kontrol } & \multicolumn{2}{|c|}{ Perlakuan } & & \\
\hline & & $\begin{array}{l}\text { Jumlah } \\
\text { (Individu) }\end{array}$ & $\begin{array}{l}\text { Berat } \\
(\mathrm{kg})\end{array}$ & $\begin{array}{l}\text { Jumlah } \\
\text { (Individu) }\end{array}$ & $\begin{array}{l}\text { Berat } \\
(\mathrm{kg})\end{array}$ & $\begin{array}{c}\text { Jumlah } \\
\text { (Individu) }\end{array}$ & $\begin{array}{l}\text { Berat } \\
(\mathrm{kg})\end{array}$ \\
\hline \multirow[t]{4}{*}{1.} & Demersal & & & & & & \\
\hline & a. Kelompok udang & 126 & 3.27 & 262 & 7.52 & 388 & 10.80 \\
\hline & b. Kelompok kepiting & 11 & 216.00 & 27 & 525.00 & 38 & 741.00 \\
\hline & c. Kelompok ikan & 74 & 3.12 & 148 & 10.39 & 222 & 13.51 \\
\hline \multirow[t]{2}{*}{2.} & Non demersal & 66 & 772.00 & 144 & 1.65 & 210 & 2.43 \\
\hline & Total & 277 & 7.38 & 581 & 21.10 & 858 & 27.47 \\
\hline
\end{tabular}

Jumlah total organisme demersal yang tertangkap sebanyak 648 individu atau $75.52 \%$ dari seluruh jumlah tangkapan dengan berat $25.05 \mathrm{~kg}(91.17 \%)$. Sementara organisme non demersal 210 individu $(24.48 \%)$ dengan bobot $2.43 \mathrm{~kg}$ $(8.83 \%)$. Organisme demersal lebih banyak tertangkap oleh trammel net dibandingkan dengan non demersal. Ini dapat dipahami karena organisme demersal memiliki habitat di dasar perairan. Seluruh organisme tersebut hanya dapat ditangkap dengan jenis alat tangkap yang dioperasikan di dasar perairan. Trammel net, menurut Puspito (2009b), dioperasikan di dasar perairan untuk menangkap jenis-jenis organisme demersal, seperti ikan yang hidup pada habitat yang sama dengan udang. Jenis tangkapan trammel net didominasi oleh kelompok udang yang terdiri atas udang putih (Penaeus merguensis), udang ronggeng (Harpiosquilla raphidea), udang windu (Penaeus monodon) dan udang kipas (Thenus orientalis). Jumlahnya mencapai 388 individu. Udang termasuk hewan bentik yang mendiami permukaan dasar perairan. Pergerakannya relatif rendah dengan jarak ruaya yang tidak jauh Wibowo et al. (2007); Badrudin et al. (2011); Murachman et al. (2010); Mulya et al. (2011); Buwono et al. (2015) menyebutkan udang umumnya hidup di lingkungan dengan substrat lumpur, lumpur berpasir dan pasir berlumpur. Kedalamannya, menurut Mulya et al. (2011) bervariasi karena sangat tergantung pada fase hidupnya. Khusus udang putih, habitatnya berada pada kedalaman 5-45 m (Poernomo 1997; Wibowo et al. 2007).

Sebanyak 10 jenis ikan demersal (222 individu) tertangkap oleh trammel net. Masing-masing adalah gulamah (Johnius $s p$.$) , pepetek (Leiognathus sp.), lidah$ (Cynoglossus lingua), buntal (Tetraodon sp.), pari (Dasyatis sp.), baji-baji (Grammpolites scaber), manyung (Arius thalassinus), sebelah (Psetodes erumer), sotong (Sepia sp.) dan kerong-kerong (Terapon theraps). Mahiswara (2004) menyatakan bahwa sumberdaya ikan demersal di wilayah intertidal memiliki keanekaragaman hayati yang tinggi. Peluang beragam jenis ikan demersal tertangkap oleh trammel net sangat tinggi.

Jumlah hasil tangkapan kelompok kepiting sebanyak 38 individu yang terdiri atas 12 kepiting dan 26 rajungan. Jumlah tangkapan rajungan yang relatif sedikit dikarenakan waktu penelitian bertepatan dengan musim pemijahan rajungan yang terjadi antara Januari-Februari (Yusfiandayani dan Sobari 2011). Rajungan pada bulan tersebut sedang memijah di perairan dengan kedalaman mencapai $65 \mathrm{~m}$ angkapan yang sangat sedikit lebih disebabkan oleh daerah penangkapannya yang tidak sesuai. Menurut Soim 1996, habitat kepiting adalah substrat lumpur yang berada dekat dengan mangrove.

Jenis organisme non demersal yang tertangkap hanya 1 jenis, yaitu bilis (Thyrissa hamiltoni1) sejumlah 210 individu $(2.43$ $\mathrm{kg})$. Bilis hidup pada pertengahan kolom perairan dan memiliki pola migrasi harian ke perairan pantai sehingga tertangkap oleh trammel net. Selain itu, musim penangkapannya berlangsung pada musim barat antara Desember-Februari (Nasution et al. 2015), atau bertepatan dengan waktu penelitian.

\section{Jumlah organisme tangkapan berdasarkan konstruksi trammel net}

Hasil uji kenormalan KolomogrovSmirnov dan uji homogenitas terhadap hasil tangkapan trammel netmenunjukkan bahwa data hasil tangkapan menyebar normal dan bersifat homogen. Perhitungan lanjutan dengan uji statistik parametrik ANOVA RAL memperoleh Fhitung $>$ Ftabel $(19.47>3.93)$ pada $\mathrm{a}=0.05$. Ini berarti Ho ditolak, maka jumlah hasil tangkapan kedua konstruksi trammel net berbeda nyata. Berdasarkan hasil perhitungan ini, penambahan posisi kekenduran dapat meningkatkan jumlah tangkapan trammel net.

Jumlah tangkapan trammel net TP dan TTK sangat berbeda. Trammel net TP menghasilkan jumlah tangkapan sebanyak (Nugraheni et al. 2015). Jumlah kepiting 581 individu atau $67.72 \%$ dari jumlah total hasil tangkapan, sedangkan trammel net kontrol (TK) 277 individu (32.28\%). Hal ini sangat 
berhubungan dengan konstruksi trammel net (Matuda 1963). Panjang dan tinggi inner net kedua konstruksi trammel net adalah sama. Penggunaan 1 kekenduran inner net pada trammel net TK mengakibatkan kekenduran hanya terpusat pada bagian bawah trammel net, sedangkan bagian atasnya dalam kondisi tegang. Sementara itu, kekenduran trammel net TP tersebar pada 3 posisi, yaitu bawah, tengah dan atas. Implikasinya adalah peluang organisme air tertangkap oleh trammel net TP menjadi lebih tinggi dibandingkan dengan trammel net TK.

\section{Sebaran hasil tangkapan pada jaring}

Sebaran jumlah organisme yang tertangkap, baik oleh trammel net kontrol (TK) maupun perlakuan (TP), ditunjukkan pada Gambar 4. Trammel net TK terbagi atas posisi bawah dan atas, sedangkan trammel net TP terdiri atas posisi bawah, tengah dan atas. Kelompok udang, ikan demersal dan non demersal tertangkap pada semua bagian jaring. Sementara kelompok kepiting hanya tertangkap pada bagian bawah. Menurut Soim (1996), kepiting termasuk hewan bentik yang aktif pada malam hari (nocturnal) dan membenamkan diri di lumpur pada siang hari. Pengoperasian trammel net yang dilakukan pada siang hari dengan cara menyapu permukaan dasar perairan mengakibatkan kepiting hanya tertangkap oleh bagian bawah trammel net.
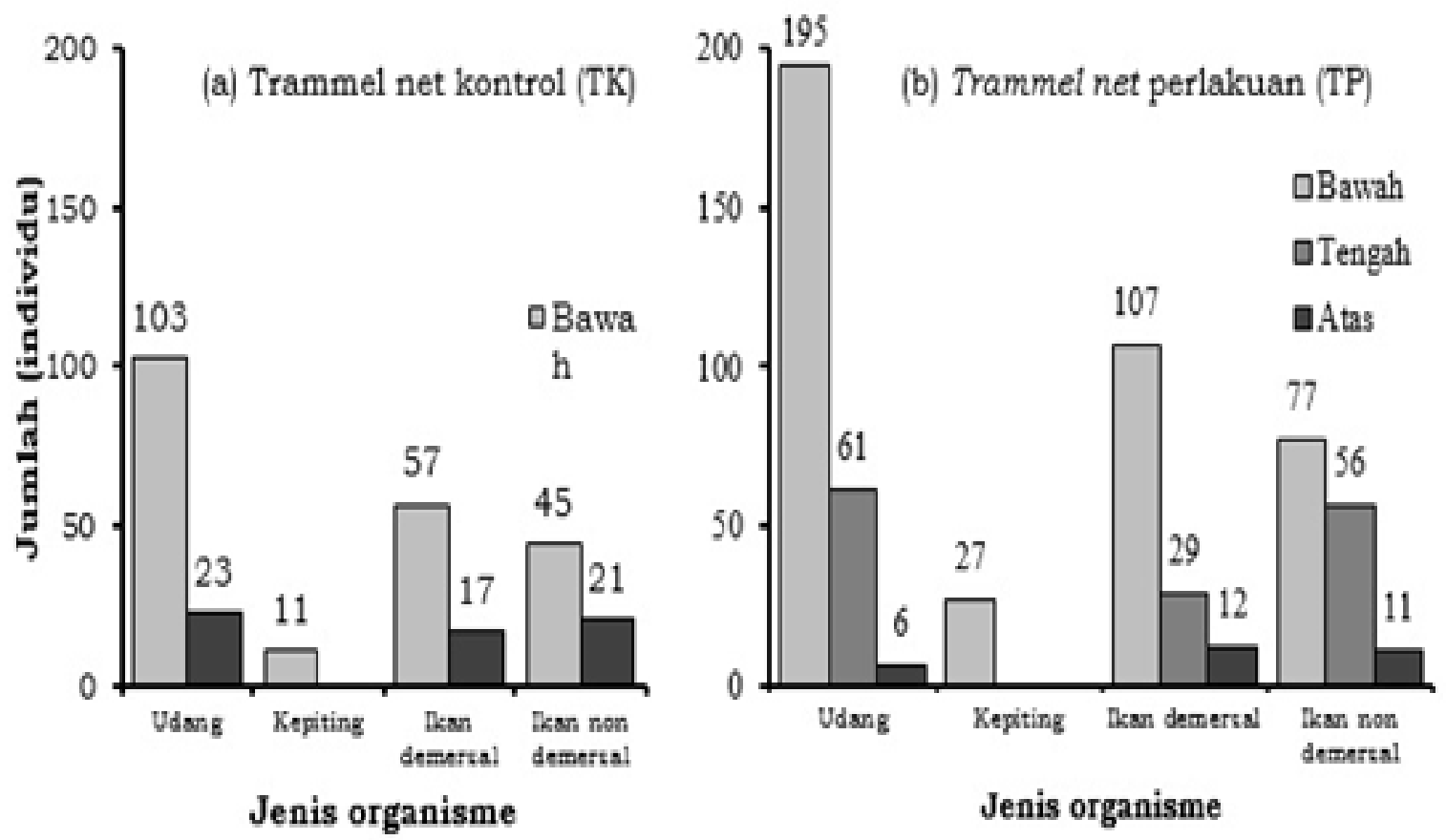

Gambar 4. Sebaran jumlah organisme yang tertangkap oleh (a) trammel net control (TK) dan (b) perlakuan (TP)

\section{Trammel net kontrol}

Organisme yang tertangkap oleh trammel net TK sebanyak 277 individu. Sejumlah 216 individu (77.98\%) diantaranya tertangkap oleh bagian bawahnya, sedangkan 61 individu (22.02\%) sisanya terperangkap oleh bagian atasnya. Perbedaan jumlah tangkapan yang sangat signifikan ini salah satunya dipengaruhi oleh perbedaan kekenduran yang terdapat pada bagian atas dan bawah trammel net. Kekenduran yang tinggi pada bagian bawah trammel net akan memudahkan organisme tertangkap, namun sebaliknya dengan kekenduran yang rendah pada bagian atas akan menyulitkan organisme terperangkap.
Kelompok organisme udang yang tertangkap pada bagian bawah trammel net kontrol (TK) sebanyak 103 individu (81.75\%), sedangkan pada bagian atas 23 individu (18.25\%). Jaring bagian bawah trammel net TK yang kendur memiliki kemampuan yang tinggi menangkap udang. Ini dibuktikan dengan cara tertangkap seluruh udang secara terpuntal.

Udang memiliki bentuk tubuh yang melengkung dan cara berenangnya dengan menghentakkan tubuh ke belakang. Reaksi udang pada saat jaring menyapu dasar perairan adalah menghempaskan tubuhnya ke atas. Sebagian udang akan menerobos masuk kedalam jaring bagian bawah. 
Awalnya, udang hanya terjerat. Selanjutnya, udang menjadi semakin terjerat dan akhirnya terpuntal akibat rontaannya dalam upaya untuk melepaskan diri dari jaring. Sementara itu, sebagian udang lainnya yang melompat dari dasar perairan mengenai jaring bagian atas yang tegang. Peluang udang tertangkap pada bagian ini sangat kecil. Udang akan kembali jatuh ke dasar perairan dan selanjutnya tersapu oleh jaring bagian bawah. Hal ini mengakibatkan jumlah udang hasil tangkapan jaring bagian atas sangat sedikit.

Bilis dan ikan demersal seharusnya lebih banyak tertangkap oleh jaring bagian atas. Kenyataannya, jumlah bilis yang tertangkap oleh jaring bagian atas hanya sebanyak 21 individu $(31.82 \%)$ atau lebih rendah dibandingkan dengan bagian bawah 45 individu (68.19\%). Demikian juga dengan ikan demersal yang tertangkap pada bagian bawah 57 individu (77.03\%) dan 17 individu $(22.97 \%)$ pada bagian atas. Penyebabnya sangat berhubungan dengan tingkah laku ikan dan dinamika trammel net ketika bergerak menyapu dasar perairan.

Selama proses penarikan, badan jaring trammelnetmenerima tekanan hidrodinamik yang disebabkan oleh pergerakan jaring melalui kolom air dan aliran air yang melalui badan jaring. Tekanan hidrodinamik yang bekerja pada jaring bagian atas lebih rendah dibandingkan dengan bagian bawahnya. Ini dikarenakan oleh kerapatan badan jaring bagian atas yang lebih rendah dibandingkan dengan bagian bawahnya. Hasil ujicoba menggunakan model trammel net didapatkan bahwa tampilan sisi jaring bagian atas dan bawah cukup berbeda (Gambar 5a). Badan jaring bagian atas agak lurus membentuk suatu sudut kemiringan, sedangkan bagian bawahnya berbentuk cembung, terutama pada bagian inner net-nya. Fungsi jaring bagian atas menjadi seperti penghadang dan pengarah, sedangkan bagian bawahnya sebagai penampung. Menurut Hajar (2012) bilis merupakan ikan pelagis kecil yang memiliki pergerakan renang vertikal. Selanjutnya Telleng et al. (2012) menambahkan bahwa ikan demersal akan bergerak sangat aktif ke arah vertikal untuk meloloskan diri dari alat tangkap. Menurutnya, ikan akan menghindari alat tangkap dengan cara berenang mengikuti dinding alat tangkap. Ikan yang berenang membentuk sudut $a<90^{\circ}$ terhadap jaring bagian atas akan bergerak menjauhi trammel net. Pergerakan ikan dengan sudut $\mathrm{a}=90^{\circ}$ akan menghasilkan 2 kemungkinan, yaitu menjauhi jaring atau turun ke arah bawah jaring. Sementara pergerakan ikan dengan sudut $a>90^{\circ}$ akan menukik dan terperangkap pada jaring bagian bawah. Ini menyebabkan bilis dan ikan demersal tertangkap lebih banyak oleh jaring bagian bawah dibandingkan dengan bagian atasnya.

\section{Trammel net perlakuan}

Trammelnetperlakuan(TP) menangkap 581 individu. Jumlah tangkapan terbanyak terdapat pada jaring bagian bawah sebanyak 406 individu (69.88\%), selanjutnya bagian tengah 146 individu (25.13\%) dan bagian atas 29 individu (4.99\%). Jenis udang yang tertangkap oleh bagian bawah jaring sebanyak 195 individu $(74.43 \%)$, bagian tengah 61 individu (23.28\%) dan bagian atas 6 individu (2.29\%). Udang merupakan organisme dasar yang bergerak pasif dan seharusnya hanya tertangkap oleh jaring bagian bawah. Menurut Suharyanto (2003) dan Mastu (2015), udang dapat melompat hingga ketinggian 12-30 cm ketika terganggu. Hal ini menjadi penyebab kenapa udang juga tertangkap oleh jaring bagian tengah dan atas. Ketinggian ketiga posisi kekenduran yang berbeda menyebabkan udang lebih banyak dan mudah tertangkap oleh jaring bagian bawah, selanjutnya tengah dan atas.

Peluang bilis tertangkap oleh setiap bagian jaring seharusnya sama. Faktanya, jumlah tangkapan terbanyak terdapat pada jaring bagian bawah, yaitu sebanyak 77 individu $(5.47 \%)$, selanjutnya menurun pada jaring bagian tengah 56 individu (38.89\%) dan atas 11 individu (7.64\%). Pola sebaran jumlah tangkapan yang sama juga terjadi pada ikan demersal, yaitu bawah 107 individu $(72.30 \%)$, tengah 29 individu $(19.59 \%)$ dan atas 12 individu (8.11\%). Gambar 4(b) menunjukkan sebaran jumlah hasil tangkapan trammel net perlakuan (TP).

Tampilan sisi trammel net perlakuan TP ketika dilakukan penarikan diilustrasikan pada Gambar 5b. Gaya hidrodinamika yang bekerja pada badan jaring menyebabkan tampilan sisi trammel net pada setiap posisi kekenduran agak berbeda. Posisi jaring outer net pada bagian atas trammel net mendekati horizontal, sehingga jaring inner net yang dibentuknya agak sedikit mendatar. Kondisi ini menjadikan jaring inner net hanya sedikit membentuk kantong. Konsekuensinya adalah jaring inner net bagian atas cenderung hanya berfungsi sebagai penghadang dan pengarah ikan untuk meloloskan diri. Sementara itu, jaring inner net sudah membentuk kantong pada trammel net bagian tengah dan bawah. Ikan yang berenang dengan sudut $a<90$ o terhadap jaring bagian atas akan terperangkap atau meloloskan diri. Adapun ikan yang bergerak dengan sudut $\mathrm{a}=900$ atau $\mathrm{a}>900$ akan terperangkap atau berenang mengikuti jaring menuju bagian tengah dan bawah. Sementara itu, pergerakan ikan menuju jaring bagian tengah dengan berbagai sudut a akan tertahan dan sebagian lainnya bergerak menuju jaring bagian bawah. Ikan yang tertangkap oleh jaring bagian bawah merupakan ikan yang tidak tertangkap 
oleh jaring bagian atas dan tengah serta ikan yang memang berenang menuju jaring bagian bawah.

\section{Kecenderungan posisi tertangkapnya ikan pada trammel net}

Hasil penelitian membuktikan bahwa seluruh bagian trammel net, baik kontrol (TK) maupun perlakuan (TP), mampu menangkap udang dan ikan. Berdasarkan hasil pengamatan langsung, trammel net kontrol sebenarnya menangkap organisme air pada bagian bawah, di antara pertengahan jaring atau disebut sebagai tengah dan di bawah tali ris atas atau atas trammel net.

Jumlah total hasil tangkapan tertinggi trammel net sebenarnya adalah jenis-jenis ikan yang terdiri atas ikan demersal dan non demersal sebanyak 432 individu, sedangkan udang 388 individu. Khusus untuk ikan, jumlah tangkapan terbanyak terdapat pada bagian bawah trammel net, selanjutnya tengah dan atas. Perbandingannya adalah 12,75 : 3,75 : 1 untuk trammel net TK dan trammel net TP $8: 3,70: 1$. Gambar 6 menunjukkan sebaran jumlah hasil tangkapan ikan berdasarkan posisi pada trammel net.

Jumlah hasil tangkapan ikan lebih banyak tersebar pada trammel net bagian bawah dan diikuti oleh tengah. Trammel net bagian atas lebih berfungsi sebagai penghadang dan pengarah pergerakan ikan. Oleh karena itu, penambahan kekenduran pada bagian atas trammel netTP sebenarnya tidak terlalu mempengaruhi jumlah hasil tangkapan. Berdasarkankan Gambar 5(b), performa bagian atas trammel net TP tidak jauh berbeda dengan TK. Dengan demikian, penambahan kekenduran pada trammel net sebaiknya hanya difokuskan pada bagian bawah dan tengah.

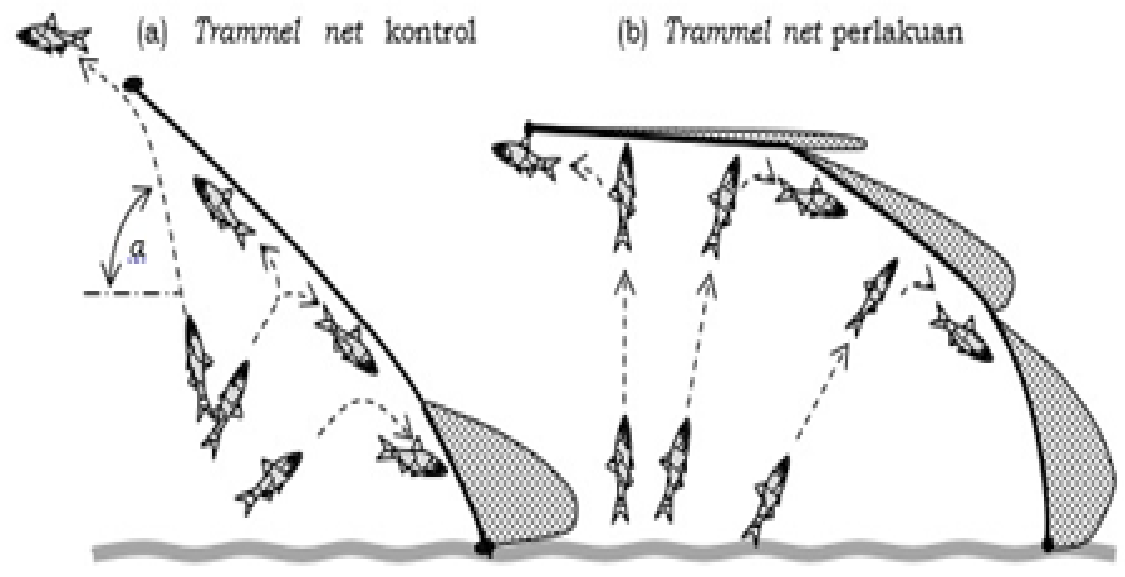

Gambar 5. Ilustrasi tampilan sisi trammel net dan pola pergerakan ikan 


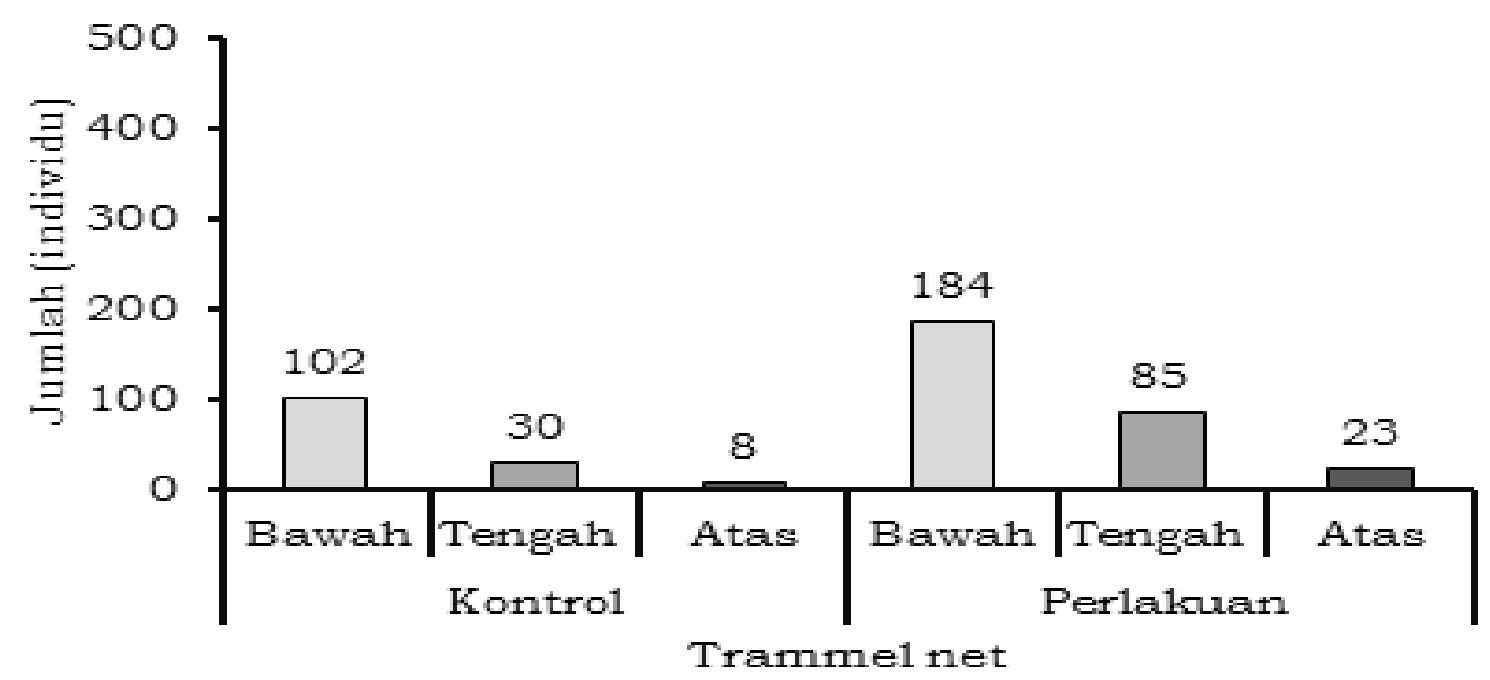

Gambar 6. Sebaran jumlah tangkapan berdasarkan posisi pada trammel net

\section{KESIMPULAN DAN SARAN}

Pengoperasian trammel net dengan satu kekenduran (TK) atau tiga kekenduran (TP) tidak mempengaruhi komposisi jenis hasil tangkapan. Masing-masing trammel net menghasilkan jenis tangkapan yang sama, yaitu 4 jenis udang, 10 jenis ikan demersal, 2 jenis kepiting dan 1 jenis ikan non demersal. Penambahan kekenduran dapat meningkatkan hasil tangkapan. Trammel net TP menangkap 581 individu $(20.10 \mathrm{~kg})$, atau lebih tinggi dibandingkan dengan trammel net TK 277 individu (7.38 $\mathrm{kg})$.

\section{DAFTAR PUSTAKA}

Badrudin, Aisyah, Ernawati T. 2011. Kelimpahan stok sumber daya ikan demersal di perairan sub area laut Jawa. J Lit Perikan Indo. 17(1):11-21.

Buwono YR, Ardhana LPG, Sudarma M. 2015. Potensi fauna akuatik ekosistem hutan mangrove di kawasan Teluk Pangpang Kabupaten Banyuwangi. Ecotropic 9:28-33.

Hajar. 2012. Fish behaviour utilization on capture process of "Jaring Perangkap Pasif” (Set Net, Teichi Ami) Inmallasoro Bay, Jeneponto Regency. Fis Res Utilization. 14.

Irhamsyah. 2002. Studi pembentukan kantong pada Trammel net [Tesis]. Bogor (ID): Institut Pertanian Bogor.

Matjik AS, Sumertajaya M. 2006. Perancangan percobaan (dengan aplikasi SAS dan minitab). Bogor (ID): IPB Pr.

Mahiswara. 2004. Analisis hasil tangkapan sampingan trawl udang yang dilengkapi perangkat seleksi TED tipe super shooter [Tesis]. Bogor
(ID): Fakultas Pascasarjana, Institut Pertanian Bogor.

Mastu L. 2015. Adaptasi dan fisiologi Udang. www. Laudekhairummastufpik. blogspot.co.id /2012/05/adaptasidan-fisiologi udang.html.[10 Maret 2016].

Matuda Ko. 1963. On the mechanical characters of the sweeping trammel net-1. Bulletin of Jpn Soc Sci Fish. 29(2):135-138.

Mulya MB, Bengen DG, Kaswadji RF, Riani E. 2011. Distribusi dan pola pertumbuhan udang putih (Penaeus merguensis de Man) di Ekosistem Mangrove Percut Sei Tuan Sumatera Utara. Omni Akuatik 10(13):49-56.

Murachman, Hanafi N, Soemarno, Muhammad S. 2010. Model polikultur udang windu (Penaeus monodon Fab), Ikan Bandeng (Chanos chanos Forskal) dan Rumput Laut (Gracilaria sp.) Secara Tradisional. JPAL. 1(1):110.

Nasution AK, Sari TEY, Usman. 2015. Fishing season review bilis/teri (Stelopherus $S p p$.) in the district of asam waters strait Meranti Islands Province Riau. $1-10$.

Nugraheni DI, Fahrudin A, Yonvitner. 2015. Variasi ukuran lebar karapas dan kelimpahan rajungan (Portunus pelegicus Linnaeus) di Perairan Kabupaten Pati. J ITKT. 7(2):493-510.

Purnomo A, Budiman, Suryadi A, Harun. 1997. Identifikasi sumberdaya ikan demersal di perairan selatan Kalimantan Tengah dengan KM.SFDP 03. BPPI Semarang.

Puspito G. 2009a. Gaya-gaya eksternal pada alat penangkapan ikan. Bogor (ID): Departemen Pemanfaatan Sumberdaya Perikanan, FPIK, IPB. 
Puspito G. 2009b. Pengaruh arus terhadap tegangan dan bentuk kelengkungan model trammel net. Jurnal Mangrove dan Pesisir 9(1): 38-47.

Soim A. 1996. Pembesaran kepiting. Jakarta (ID): Penebar Swadaya.

Stergiou KI, Moutopoulos DK, Soriguer MC, Puente E, Lino PG, Zabala C, Monteiro P, Errazkin LA, Erzini K. 2006. Trammel net catch species composition, catch rates and metiers in Southern European Waters: A Multivariate Approach. Fish Res. 79:170-182.

Suharyanto. 2003. Kajian respon udang galah terhadap kejutan listrik arus bolak balik dalam tangki percobaan skala laboratorium [Tesis]. Bogor
(ID): Fakultas Pascasarjana, Institut Pertanian Bogor.

Telleng ATR, Labaro IL, Takahelo ED. 2012. Pola meloloskan diri ikan kuwe dari alat tangkap jala buang di Perairan Kelurahan Papusungan Kota Bitung Provinsi Sulawesi Utara. JTPK. 1(2):38-42.

Wibowo P, Hartoko A, Ghofar A. 2007. Kepadatan udang putih (Penaeus merguensis De Man) di Sekitar Perairan Semarang. Jurnal Pasir Laut 2(2):1-29.

Yusfiandayani R, Sobari MP. 2011. Aspek bioteknik dalam pemanfaatan sumberdaya rajungan di perairan Teluk Banten. JTPK. 1(2):71-80. 